\title{
"The effect of CEO turnover on audit report lag and management discretionary report lag: evidence from Korea”
}

\begin{tabular}{ll} 
AUTHORS & $\begin{array}{l}\text { Chang-Hyun Bae } \\
\text { Yong-Sang Woo }\end{array}$ \\
& $\begin{array}{l}\text { Chang-Hyun Bae and Yong-Sang Woo (2016). The effect of CEO turnover on } \\
\text { audit report lag and management discretionary report lag: evidence from Korea. } \\
\text { Investment Management and Financial Innovations, 13(1), 61-66. } \\
\text { doi:10.21511/imfi.13(1).2016.05 }\end{array}$ \\
\hline ARTICLE INFO & http://dx.doi.org/10.21511/imfi.13(1).2016.05 \\
\hline DOI & Friday, 04 March 2016 \\
\hline RELEASED ON & "Investment Management and Financial Innovations" \\
\hline JOURNAL & LLC "Consulting Publishing Company "Business Perspectives" \\
\hline FOUNDER &
\end{tabular}

NUMBER OF REFERENCES

0

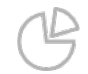

NUMBER OF FIGURES

0

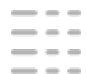

NUMBER OF TABLES

0

(C) The author(s) 2022. This publication is an open access article. 


\title{
The effect of CEO turnover on audit report lag and management discretionary report lag: evidence from Korea
}

\begin{abstract}
This study empirically investigates the effect of a CEO turnover on audit report lag (ARL), discretionary report lag (DRL) and total report lag (TRL). The object of this study is to provide empirical evidence for the responses of both the CEO and the external auditor on audit risk increases and information asymmetry that occur as a result of a CEO turnover. According to the previous study on CEO turnovers, the CEO turnover would increase audit risk and information asymmetry (Sohn et al., 2014). In this situation, the CEO has an incentive to provide timely information to decrease the monitoring costs and cost of debt (Lee et al., 2008). It is expected that an external auditor spends a large amount of time on audit procedures to lower the audit risk when the CEO changes. Therefore, the CEO turnover would have a conflicting effect on the ARL and DRL.

The results of the analysis are as follows. First, the ARL increases and DRL decreases when the CEO changes, which suggests that an external auditor spends a great amount of time on audit procedures to lower the audit risk because the audit risk increases when the CEO changes. A new CEO provides information faster to reduce monitoring costs and cost of debt that occur due to information asymmetry. Second, the ARL increases and DRL decreases as the frequency of CEO turnover increases. An external auditor would estimate the audit risk as being high if the CEO changes more frequently. To lower the audit risk to an acceptable level, many audit hours are spent on audit procedures by an external auditor, which increases the ARL. A new CEO has an incentive to provide timely information when the CEO changes more frequently. Thus, the DRL decreases as the frequency of CEO turnover increases.
\end{abstract}

Keywords: CEO turnover, audit report lag, management discretionary report lag.

JEL Classification: M42.

\section{Introduction}

Previous studies on audit report lag (ARL) have reported that this lag increases when the audit risk is high and information asymmetry is serious (Whittred, 1980; Ettredge et al., 2006; Lee and Jahng, 2008; Lee et al., 2008). These previous studies insist that the ARL increases because the auditor spends more time in the audit process to decrease the audit risk and information asymmetry to an acceptable level when the audit risk is high and information asymmetry is serious. CEO turnover is expected to affect information asymmetry. According to a previous study on CEO turnover, audit risk and information asymmetry increase around the time of a CEO turnover (Sohn et al., 2014). Therefore, there would be a significant relation between CEO turnover and ARL. Because monitoring costs and the cost of debt increase when information asymmetry is serious, the CEO has an incentive to improve the timeliness of accounting information to reduce information asymmetry (Lee et al., 2008). However, the external auditor would then spend more time with audit procedures, and this extra time spent with auditing would increase the ARL because the external auditor estimates the audit risk as being high. Thus, the object of this study is to empirically prove these conflicting inferences.

(c) Chang-Hyun Bae, Yong-Sang Woo, 2016.

Chang-Hyun Bae, Ph.D. Candidate, School of Business, Yonsei University, Korea.

Yong-Sang Woo, Associate Professor, School of Business, Ewha Womans University, Korea.
The aim of this study is to present the empirical evidence for the reaction of the CEO and external auditor in the event of a CEO turnover, which affects both the audit risk and information asymmetry. In other words, the aim of this study is to prove whether the timeliness of the information is improved for reducing information asymmetry or whether many audit hours are spent reducing the audit risk. This paper is organized as follows. Previous studies on CEO turnover and the ARL are discussed, and the hypotheses are developed in the next section. The research model is provided in the third second section. The empirical results are presented in the third section. Final section gives the conclusion.

\section{Literature review and hypothesis development}

1.1. CEO turnover. Moore (1973) reports that companies that change management tend to reduce income discretionarily. Strong and Meyer (1987) state that an asset writedown often occurs in the event of a change in senior management. Beatty and Zajac (1987) find that CEO changes are significantly associated with a reduction in the value of the firm. They also find that this negative response in stock price is stronger when the CEO successors are insiders. Friedman and Singh (1989) find evidence similar to that of Beatty and Zajac (1987), which is that positive abnormal stock returns are observed when the presuccession performance is poor. In contrast, a negative abnormal stock return is observed in the event of a satisfactory presuccession performance. 
Warner et al. (1988) find that CEO turnover is not significantly associated with an abnormal return. However, Weisbach (1988) and Denis and Denis (1995) report that positive abnormal stock returns are observed on the dates of CEO change disclosures. Francis et al. (1996) find that the frequency and magnitude of write-offs is significantly associated with a recent change in management. Denis et al. (1997) state that the likelihood of a CEO turnover is high when the CEO ownership percentage is low. They also find that the likelihood of CEO turnover is high when there is an outside blockholder. Suchard et al. (2001) find a significant relationship between CEO turnover and the lagging performance of company. Lausten (2002) states that the possibility of a CEO turnover is high when the firm performance is poor and that the relationship between CEO turnover and firm performance is strengthened by the status of the chairman of the board and family ties within the management and ownership of the company. Brunello et al. (2003) find that the possibility of CEO turnover is high when firm performance is poor. However, there is no significant association between CEO turnover and firm performance when the controlling shareholder is the CEO. Desai et al. (2006) find that CEO turnover occurs frequently in companies that attempt to present earnings restatements through accounting changes. Adams and Mansi (2009) find that CEO turnover is negatively related to bondholder value and positively related to stockholder value. They also find that the stock market reaction of a forced CEO turnover with an outsider successor is more positive than that of a voluntary CEO turnover with an insider successor.

1.2. Audit report lag (ARL) and management discretionary report lag (DRL). Previous studies on ARL include the characteristics of a company and the external auditor, which affect the ARL (Whittred, 1908; Whittred and Zimmer, 1984; Ashton et al., 1987; Bamber et al., 1993; Knechel and Payne, 2001) and the effect of a new system on the ARL (Ettredge et al., 2006). Whittred and Zimmer (1984) find that companies in financial distress have long ARLs. Ashton et al. (1987) find that the ARL is long for unlisted companies, nonfinancial companies, companies that receive qualified audit opinions, companies with a fiscal year-end in a month other than December, and companies with poor internal control systems. Bamber et al. (1993) find that the ARL is long when significant audit work is required. However, incentives to provide timely reports decrease the length of the ARL. Knechel and Payne (2001) find that incremental audit efforts, the presence of tax issues, and using less experienced auditors increase the ARL. Lee and Jahng (2008) find that non-audit fees paid to incumbent auditors, using a Big 4 auditor, unqualified audit opinions, abnormal audit hours, and tax services provided by incumbent auditors decrease the ARL. Lee et al. (2008) find that the DRL and total report lag (TRL) are short in multinational firms. These previous studies find that audit risk is a determinant of both the ARL and DRL. Bae and Woo (2014) find that the ARL is positively associated and that DRL is negatively associated with analysts' forecast error.

1.3. Hypothesis development. A CEO turnover event is considered the expectation of future performance improvement or a signal of poor present performance. Lausten (2002) and Brunello et al. (2003) find that CEO turnover often occurs when the performance of a company is poor.

A new CEO tends to report earnings conservatively because he or she wants to lower the expected level of future performance (Moore, 1973; Strong and Meyer, 1987). The new CEO is likely to reluctantly disclose information that addresses earnings management, which can aggravate information asymmetry. Sohn et al. (2014) find that the possibility of an unfaithful disclosure designation for a firm and the accuracy of an analyst forecast decrease when the CEO changes. Therefore, the CEO turnover would increase earnings management and aggravate information asymmetry. Because monitoring costs and the cost of debt increase when information asymmetry is serious, the CEO has an incentive to disclose timely information for decreasing information asymmetry (Lee et al., 2008). However, a significant amount of effort is spent in the auditing process because an external auditor would estimate the audit risk as being high in the event of a CEO turnover. The increase in audit effort increases the ARL ${ }^{1}$. The first hypothesis is developed as follows.

Hypothesis 1: Ceteris paribus, CEO turnover is significantly positively associated with an audit report lag (ARL).

As we already explained, a new CEO would disclose timely information to decrease monitoring costs and cost of debt when the CEO is changed because a new CEO would want to decrease information asymmetry. Therefore, the $\mathrm{DRL}^{2}$ would be short when the CEO changes. The second hypothesis is developed as follows.

\footnotetext{
${ }^{1}$ The ARL is estimated by the number of days from the fiscal year-end to the date on which the audit process is finished (Leventis and Weetman, 2004; Ettredge et al., 2006; Lee et al., 2008).

2 The DRL is estimated by the number of days from the date on which the audit process is finished to the earnings release date (Leventis and Weetman, 2004; Ettredge et al., 2006; Lee et al., 2008).
} 
Hypothesis 2: Ceteris paribus, CEO turnover is significantly negatively associated with a management discretionary report lag (DRL).

\section{Research design}

2.1. Research model. The empirical model used to test Hypothesis 1 and 2 is as follows.

$$
\begin{aligned}
& A R L_{t}\left(D R L_{t}, T_{R L}\right)=\beta_{0}+\beta_{1} C E O_{t}+\beta_{2} S_{Z I Z E_{t}}+ \\
& +\beta_{3} L E V_{t}+\beta_{4} R O A_{t}+\beta_{5} L O S S_{t}+\beta_{6} S_{Q S U B_{t}}+ \\
& +\beta_{7} C R_{t}+\beta_{8} G P_{t}+\beta_{9} O W N_{t}+\beta_{10} F O R_{t}+\beta_{11} B I G_{t}+ \\
& +\beta_{12} L N N A F_{t}+\beta_{13} S_{W I T C H}+\sum I D+\sum Y D+\varepsilon_{t}
\end{aligned}
$$

where $A R L_{t}$ : the number of days from the fiscal year-end to the date on which the audit process is finished for year $t ; D R L_{t}$ : the number of days from date on which the audit process is finished to the earnings release date of year $t ; T R L_{t}$ : the number of days from the fiscal year-end to the earnings release date of year $t ; S I Z E_{t}$ : the natural logarithm of total assets at the end of year $t ; L E V_{t}$ : the debt ratio at the end of year $t ; R O A_{t}$ : the return on asset in year $t$; $L_{O S S}: 1$ if a company reports negative earnings in year $t, 0$ otherwise; $S Q S U B_{t}$ : the square root of the number of subsidiaries in year $t ; C R_{t}$ : the current ratio at the end of year $t$; $G P_{t}: 1$ if a company is included in a conglomerate, 0 otherwise; $O W N_{t}$ : the ownership percentage of the manager in year $t ; F O R_{t}$ : the ownership percentage of foreign shareholders in year $t ; B I G_{t}: 1$ if an external auditor is from the Big 4 , 0 otherwise; $L N N A F_{t}$ : the natural logarithm of nonaudit service fees in year $t ; S_{W I T C H}: 1$ if an auditor offers an initial audit service, 0 otherwise; $I D$ : industry dummy; $Y D$ : year dummy;

$A R L, D R L$, and $T R L$ are dependent variables in model (1) and represent the audit report lag, management discretionary report lag, and total report lag, respectively. The main independent variable in model (1) is $C E O$, which represents whether the CEO has changed. The other independent variables are control variables. An external auditor spends a large amount of time on an audit procedure when the size of auditee is large. However, a large auditee has an incentive to provide timely information because it has a well-organized internal control system or because there are many interested parties (Carslaw and Kaplan, 1991). Therefore, SIZE is included to control the effect of company's size on $A R L, D R L$ and TRL. When the debt ratio is high, the audit risk is also high, and an external auditor would spend a great deal of time on an audit procedure. Thus, $L E V$ is included in model (1). ROA is also used as a control variable (Jaggi and Tsui, 1999). LOSS is included to control the different reporting incentive of positive (good news) or negative earnings (bad news) (Ashton et al., 1987; Carslaw and Kaplan, 1991). SQSUB represents the complexity of the auditee. The complexity of the auditee is deepened as $S Q S U B$ increases. $C R$ is included to control the effect of the company's financial condition on $A R L, D R L$ and $T R L$. When the current ratio is low, the liquidity of a company is poor. Therefore, an external auditor would spend a large amount of time in audit procedures. When the current ratio is high, a company has sufficient current assets to pay the current liabilities. In this case, an external auditor would not spend much time on the audit procedures. When a company is included in a conglomerate, the regulatory bodies would monitor this company in various ways. Therefore, the audit risk would be low in a company that is included in a conglomerate. The low ownership percentage of a manager means that there are various interested parties and that the litigation risk is high. Therefore, an external auditor would be careful with the audit procedure, and consequently, $A R L$ would increase. As the ownership percentage of foreign shareholders increases, the audit risk would increase because the foreign investors are considered sophisticated investors who can analyze the accounting information of a company. Thus, FOR would increase the $A R L$. If an external auditor is from the Big 4, $A R L$ would be short because large audit firms have many experienced staff members and a large amount of audit resources. $L N N A F$ is used to control the effect of non-audit services by the incumbent auditor on $A R L$ because audit hours would be reduced by the understanding of auditee from non-audit services (Knechel and Payne, 2001; Lee and Jahng, 2008). If an external auditor offers an initial audit service, it is necessary to spend more time in the audit procedure because understanding the entire situation of auditee is essential. This would make ARL long.

2.2. Sample selection. Our sample consists of listed companies on the Korean Exchange (KRX) from 2003 to 2010. Only firm years with a fiscal year-end on December 31 and non-financial companies are included in our sample. Firm years for which financial, ownership percentage and external auditor data are available in both the TS-2000 and KisValue are included in our sample. The data for CEO turnover are collected from the Corporate Disclosure Channel KIND, which is operated by KRX (http://kind.krx.co.kr). The final sample consists of 3,147 firm years.

\section{Empirical results}

3.1. Descriptive statistics. Descriptive statistics of variables used in this study are presented in Table 1.

Table 1. Descriptive statistics

\begin{tabular}{|l|c|c|c|c|c|}
\hline \multicolumn{1}{|c|}{ Variables } & Mean & St. dev. & Min & Median & Max \\
\hline$A R L$ & 46.757 & 14.613 & 18 & 46 & 76 \\
\hline$D R L$ & 20.187 & 13.067 & 1 & 20 & 56 \\
\hline
\end{tabular}


Table 1 (cont.). Descriptive statistics

\begin{tabular}{|l|c|c|c|c|c|}
\hline Variables & Mean & St. dev. & Min & Median & Max \\
\hline TRL & 66.946 & 9.524 & 42 & 68 & 89 \\
\hline CEO & 0.295 & 0.456 & 0 & 0 & 1 \\
\hline SIZE & 19.739 & 1.563 & 16.769 & 19.498 & 23.915 \\
\hline LEV & 0.462 & 0.193 & 0.063 & 0.469 & 0.895 \\
\hline ROA & 0.026 & 0.091 & -0.466 & 0.036 & 0.206 \\
\hline LOSS & 0.187 & 0.390 & 0 & 0 & 1 \\
\hline SQSUB & 3.553 & 3.841 & 0 & 3.000 & 18.466 \\
\hline CR & 1.770 & 1.743 & 0.192 & 1.298 & 12.443 \\
\hline GP & 0.278 & 0.448 & 0 & 0 & 1 \\
\hline OWN & 0.412 & 0.168 & 0.066 & 0.405 & 0.814 \\
\hline FOR & 0.114 & 0.152 & 0 & 0.042 & 0.652 \\
\hline BIG & 0.701 & 0.458 & 0 & 1 & 1 \\
\hline LNNAF & 3.998 & 5.187 & 0 & 0 & 13.741 \\
\hline SWITCH & 0.189 & 0.392 & 0 & 0 & 1 \\
\hline
\end{tabular}

Note: See Model (1) for definitions of the variables used.

The mean and median of $A R L$ is approximately 46, which means that the number of days from the fiscal year-end to the date on which the audit process is finished is 46 days. The mean of $C E O$ is 0.295 , which means that $30 \%$ of our sample companies changed CEOs. The mean and median of $L E V$ are each approximately $46 \%$. This result shows that the total equity is larger on average than the total liabilities in our sample. The mean of LOSS is 0.187 , which means that $19 \%$ of our sample report net loss in a sample period. The mean of $C R$ is 1.770. This result shows that the total current assets are greater than total current liabilities. The mean of $G P$ is 0.278 , which means that $28 \%$ of our samples are included in a conglomerate. There is a large difference between the mean and the median of $F O R$. This result states that foreign investors invest in some companies intensively. The mean of $B I G$ is 0.701 , which means that $70 \%$ of our samples are audited by Big 4 audit firm.

3.2. Regression results. Table 2 presents the results of the regression analysis in Hypotheses 1 and 2.

Table 2. Regression results

\begin{tabular}{|c|c|c|c|c|c|c|}
\hline & \multicolumn{2}{|c|}{$A R L$} & \multicolumn{2}{|c|}{$D R L$} & \multicolumn{2}{|c|}{$T R L$} \\
\hline & Coefficients & t-stat & Coefficients & t-stat & Coefficients & t-stat \\
\hline Intercept & 41.752 & $8.13^{\star \star \star}$ & 43.669 & $9.27^{\star \star \star}$ & 83.917 & $25.23^{\star \star \star}$ \\
\hline CEO & 1.789 & $3.25^{\star \star \star}$ & -1.294 & $-2.56^{\star \star \star}$ & 0.511 & 1.43 \\
\hline SIZE & -0.107 & -0.39 & -1.064 & $-4.24^{\star \star *}$ & -1.086 & $-6.12^{* \star \star}$ \\
\hline LEV & 3.494 & $2.01^{\star \star}$ & 2.044 & 1.28 & 5.469 & $4.87^{\star \star \star}$ \\
\hline$R O A$ & -19.055 & $-4.70^{\star \star \star}$ & 11.533 & $3.10^{\star \star \star}$ & -7.523 & $-2.87^{\star \star \star}$ \\
\hline LOSS & 0.857 & 0.95 & 0.686 & 0.83 & 1.539 & $2.64^{\star \star \star}$ \\
\hline SQSUB & 0.585 & $6.93^{\star \star \star}$ & -0.212 & $-2.74^{\star \star \star}$ & 0.340 & $6.22^{\star \star \star}$ \\
\hline$C R$ & 0.261 & 1.48 & -0.371 & $-2.29^{* *}$ & -0.086 & -0.75 \\
\hline$G P$ & -3.955 & $-5.47^{\star \star \star}$ & 2.943 & $4.43^{\star \star \star}$ & -1.014 & $-2.16^{\star \star}$ \\
\hline OWN & 1.388 & 0.87 & -0.864 & -0.59 & 0.368 & 0.36 \\
\hline FOR & -12.592 & $-6.19^{\star \star \star}$ & 6.621 & $3.55^{\star \star \star}$ & -6.334 & $-4.81^{* \star *}$ \\
\hline$B I G$ & 6.856 & $11.42^{* \star *}$ & -5.200 & $-9.44^{* * *}$ & 1.715 & $4.41^{* \star *}$ \\
\hline LNNAF & 0.047 & 0.90 & 0.041 & 0.86 & 0.089 & $2.63^{\star \star \star}$ \\
\hline SWITCH & 1.139 & $1.79^{\star}$ & 0.153 & 0.26 & 1.373 & $3.33^{\star \star \star}$ \\
\hline IND & \multicolumn{2}{|c|}{ Included } & \multicolumn{2}{|c|}{ Included } & \multicolumn{2}{|c|}{ Included } \\
\hline$Y D$ & \multicolumn{2}{|c|}{ Included } & \multicolumn{2}{|c|}{ Included } & \multicolumn{2}{|c|}{ Included } \\
\hline $\mathrm{N}$ & \multicolumn{2}{|c|}{3,147} & \multicolumn{2}{|c|}{3,147} & \multicolumn{2}{|c|}{3,147} \\
\hline $\mathrm{Adj}^{2}{ }^{2}$ & \multicolumn{2}{|c|}{0.096} & \multicolumn{2}{|c|}{0.049} & \multicolumn{2}{|c|}{0.108} \\
\hline F-value & \multicolumn{2}{|c|}{$14.43^{\star \star \star}$} & \multicolumn{2}{|c|}{$7.49^{* \star \star}$} & \multicolumn{2}{|c|}{$16.17^{\star \star \star}$} \\
\hline
\end{tabular}

Notes: $* * *, * *$ and $*$ denote significance at the $1 \%, 5 \%$, and $10 \%$ percent levels, respectively, based on a two-tailed test. See Model (1) for definitions of the variables used.

$C E O$ is significantly positively associated with $A R L$. This result means that the external auditor conducts audits conservatively in companies where the CEO changed because CEO turnover is related to the impairment of the accounting information's reliability and transparency. This attitude of an external auditor increases the ARL. Therefore, Hypothesis 1 is supported. CEO is significantly negatively associated with $D R L$. This result states that the CEO wants to reduce monitoring costs and the cost of debt by providing timely information. This result supports Hypothesis 2.

3.3. Additional analysis results. We focus on the frequency rather than the existence of CEO turnovers in the additional analysis. The audit risk would be high in companies where the CEO changes more frequently because a CEO turnover can affect the audit risk and information asymmetry. The results of the additional analysis on the relation between the frequency of CEO turnover and the ARL, DRL or TRL are shown in Table 3. 
Table 3. Additional regression results - frequency of CEO turnover

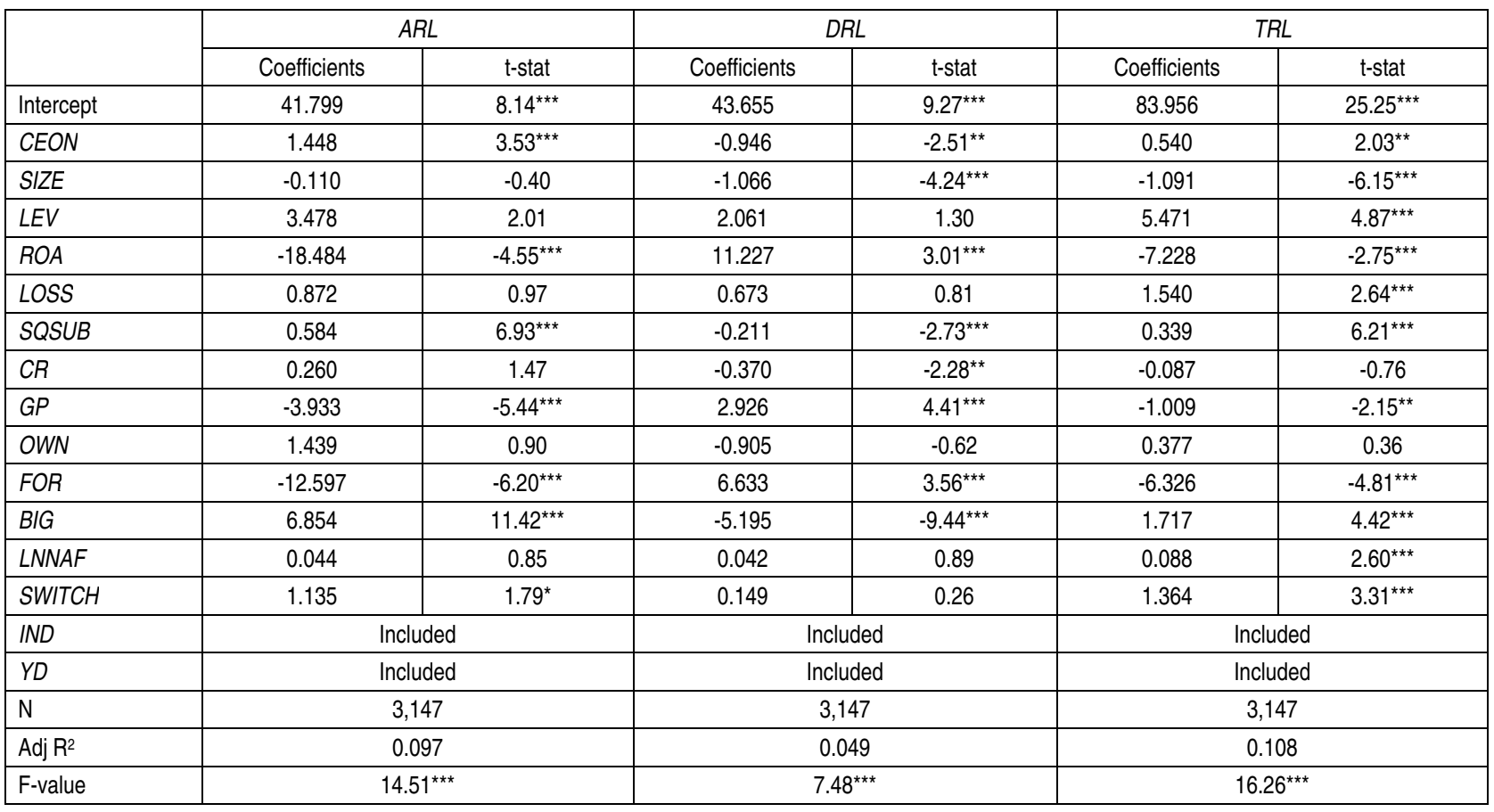

Notes: $* * *, * *$ and $*$ denote significance at the $1 \%, 5 \%$, and $10 \%$ percent levels, respectively, based on a two-tailed test. See Model (1) for definitions of the variables used.

The empirical results show that the ARL and TRL increase as the frequency of the CEO turnover increases. However, CEON is significantly negatively associated with $D R L$. This result means that an external auditor estimates that the audit risk is high when the CEO changes frequently and audit hours are spent more on audit procedures. However, a new CEO would want to decrease information asymmetry because a company must pay a large amount of monitoring cost and cost of debt in the event of an information asymmetry situation. Therefore, the new CEO will provide timely information for the interested parties of a company to decrease information asymmetry.

\section{Conclusion}

This study empirically investigates the effect of a CEO turnover on ARL, DRL and TRL. The object of this study is to provide empirical evidence for the responses of both the CEO and the external auditor on audit risk increases and information asymmetry that occur as a result of a CEO turnover. According to the previous study on CEO turnovers, the CEO turnover would increase audit risk and information asymmetry (Sohn et al., 2014). In this situation, the CEO has an incentive to provide timely information to decrease the monitoring costs and cost of debt (Lee et al., 2008). It is expected that an external auditor spends a large amount of time on audit procedures to lower the audit risk when the CEO changes. Therefore, the CEO turnover would have a conflicting effect on the ARL and DRL.

The results of the analysis are as follows. First, the ARL increases and DRL decreases when the CEO changes, which suggests that an external auditor spends a great amount of time on audit procedures to lower the audit risk because the audit risk increases when the CEO changes. A new CEO provides information faster to reduce monitoring costs and cost of debt that occur due to information asymmetry. Second, the ARL increases and DRL decreases as the frequency of CEO turnover increases. An external auditor would estimate the audit risk as being high if the CEO changes more frequently. To lower the audit risk to an acceptable level, many audit hours are spent on audit procedures by an external auditor, which increases the ARL. A new CEO has an incentive to provide timely information when the CEO changes more frequently. Thus, the DRL decreases as the frequency of CEO turnover increases.

This study provides additional evidence for the proposal of previous studies that an external auditor and the management would behave differently when the audit risk is high and information asymmetry is serious.

\section{References}

1. Adams, J.C., and S.A. Mansi. (2009). CEO Turnover and Bondholder Wealth, Journal of Banking \& Finance, 33, pp. 522-533.

2. Ashton, R.H., J.J. Willingham, and R.K. Elliott. (1987). An Empirical Analysis of Audit Delay, Journal of Accounting Research, 25 (2), pp. 275-292. 
3. Bae, C.H., and Y.S. Woo. (2014). The Effect of Audit Report Lag and Management Discretionary Report Lag on Analyst Forecasts: Evidence from Korea, Investment Management and Financial Innovations, 12 (1), pp. 318-329.

4. Bamber, E.M., L.S. Bamber, and M.P. Schoderbek. (1993). Audit Structure and Other Determinants of Audit Report Lag: An Empirical Analysis, Auditing: A Journal of Practice \& Theory, 12 (1), pp. 1-23.

5. Beatty, R.P., and E.J. Zajac. (1987). CEO Change and Firm Performance in Large Corporations: Succession Effects and Manager Effects, Strategic Management Journal, 8, pp. 305-317.

6. Brunello, G., C. Graziano and B.M. Parigi. (2003). CEO Turnover in Insider-Dominated Boards: The Italian Case, Journal of Banking \& Finance, 27, pp. 1027-1051.

7. Carslaw, C.A.P.N. and S.E. Kaplan. (1991). An Examination of Audit Delay: Further Evidence from New Zealand, Accounting and Business Research, 22 (85), pp. 21-32.

8. Denis, J.D., and D.K. Denis. (1995). Performance Changes Following Top Management Dismissals, The Journal of Finance, 50 (4), pp. 1029-1057.

9. Denis, D.J., D.K. Denis and A. Sarin. (1997). Ownership Structure and Top Executive Turnover, Journal of Financial Economics, 45, pp. 193-221.

10. Desai, H., C.E. Hogan, and M.S. Wilkins. (2006). The Reputational Penalty for Aggressive Accounting: Earnings Restatements and Management Turnover, The Accounting Review, 81 (1), pp. 83-112.

11. Ettredge, M., C. Li and L. Sun. (2006). The Impact of SOX Section 404 Internal Control Quality Assessment on Audit Delay in the SOX Era, Auditing: A Journal of Practice \& Theory, 25 (2), pp. 1-23.

12. Francis, J., D. Hanna and L. Vincent. (1996). Causes and Effects of Discretionary Asset Write-Offs, Journal of Accounting Research, 34 (Supplement), pp. 117-134.

13. Friedman, S.D., and H. Singh. (1989). CEO Succession and Stockholder Reaction: The Influence of Organizational Context and Event Content, Academy of Management Journal, 32 (4), pp. 718-744.

14. Jaggi, B., and J. Tsui. (1999). Determinants of Audit Report Lag: Further Evidence from Hong Kong, Accounting and Business Research, 30 (1), pp. 17-28.

15. Knechel, W.R., and J.L. Payne. (2001). Additional Evidence on Audit Report Lag, Auditing: A Journal of Practice \& Theory, 20 (1), pp. 137-146.

16. Lausten, M. (2002). CEO Turnover, Firm Performance and Corporate Governance: Empirical Evidence on Danish Firms, International Journal of Industrial Organization, 20, pp. 391-414.

17. Lee, H. and G. Jahng. (2008). Determinants of Audit Report Lag: Evidence from Korea - An Examination of Auditor-Related Factors, Journal of Applied Business Research, 24 (2), pp. 27-44.

18. Lee, H., V. Mande and M. Son. (2008). A Comparison of Reporting Lags of Multinational and Domestic Firms, Journal of International Financial Management and Accounting, 19 (1), pp. 28-56.

19. Leventis, S. and P. Weetman. (2004). Timeliness of Financial Reporting: Applicability of Disclosure Theories in an Emerging Capital Market, Accounting and Business Research, 34 (1), pp. 43-56.

20. Moore, M.L. (1973). Management Changes and Discretionary Accounting Decisions, Journal of Accounting Research, 11, pp. 100-107.

21. Sohn, S.K., Y.S. Oh, M.J. Kang and C.H. Bae. (2014). The Effect of CEO Change on Information Asymmetry, Journal of Applied Business Research, 30 (2), pp. 527-540.

22. Strong, J.S., and J.R. Meyer. (1987). Asset Writedowns: Managerial Incentives and Security Returns, The Journal of Finance, 42 (3), pp. 643-661.

23. Suchard, J., M. Singh, and R. Barr. (2001). The Market Effects of CEO Turnover in Australian Firms, PacificBasin Finance Journal, 9, pp. 1-27.

24. Warner, J.B., R.L. Watts, and K.H. Wruck. (1988). Stock Prices and Top Management Changes, Journal of Financial Economics, 20, pp. 461-492.

25. Weisbach, M.S. (1988). Outside Directors and CEO Turnover, Journal of Financial Economics, 20, pp. 431-460.

26. Whittred, G.P. (1980). Audit Qualification and the Timeliness of Corporate Annual Reports, The Accounting Review, 55 (4), pp. 563-577.

27. Whittred, G.P., and I. Zimmer. (1984). Timeliness of Financial Reporting and Financial Distress, The Accounting Review, 59 (2), pp. 287-295. 